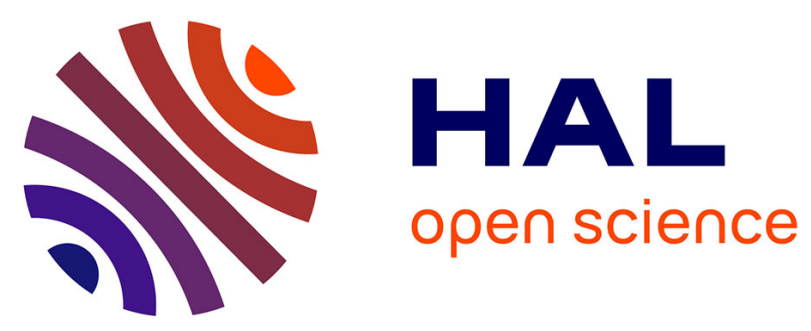

\title{
The electrochemical performance of AB3-type hydrogen storage alloy as anode material for the nickel metal hydride accumulators
}

Yassine Ben Belgacem, Chokri Khaldi, Jilani Lamloumi, Hisasi Takenouti

\section{To cite this version:}

Yassine Ben Belgacem, Chokri Khaldi, Jilani Lamloumi, Hisasi Takenouti. The electrochemical performance of AB3-type hydrogen storage alloy as anode material for the nickel metal hydride accumulators. Journal of Solid State Electrochemistry, 2016, 20 (7), pp.1949-1959. 10.1007/s10008-016-3198-3 . hal-01334909

\section{HAL Id: hal-01334909 \\ https://hal.sorbonne-universite.fr/hal-01334909}

Submitted on 27 Jun 2016

HAL is a multi-disciplinary open access archive for the deposit and dissemination of scientific research documents, whether they are published or not. The documents may come from teaching and research institutions in France or abroad, or from public or private research centers.
L'archive ouverte pluridisciplinaire HAL, est destinée au dépôt et à la diffusion de documents scientifiques de niveau recherche, publiés ou non, émanant des établissements d'enseignement et de recherche français ou étrangers, des laboratoires publics ou privés.

\section{(ㅇ)(1) $\$$}

Distributed under a Creative Commons Attribution - NonCommerciall 4.0 International 
The electrochemical performance of AB3-type hydrogen storage alloy as anode material for the nickel metal hydride accumulators

Yassine Ben Belgacem ${ }^{\mathrm{a}, \mathrm{b}}$, Chokri Khaldi, ${ }^{\mathrm{a},}$, Jilani Lamloumi ${ }^{\mathrm{a}}$, Hisasi Takenouti ${ }^{\mathrm{c}, \mathrm{d}}$

${ }^{a}$ Equipe des Hydrures Métalliques, LMMP, ENSIT", Université de Tunis, 5 Avenue Taha Hussein, 1008 Tunis, Tunisia

${ }^{\mathrm{b}}$ Faculté des Sciences de Tunis, Université de Tunis El Manar, 2092 El Manar, Tunis, Tunisia

${ }^{\mathrm{c}}$ Sorbonne Universités, UPMC Univ Paris 06, UMR 8235, Laboratoire Interfaces et Systèmes Electrochimique (LISE), 4 place Jussieu, 75252 Paris CEDEX 05, France

${ }^{\mathrm{d}}$ CNRS, UMR 8235, LISE, Case 133, 4 place Jussieu, 75252 Paris CEDEX 05, France

\footnotetext{
* Corresponding author. Tel.: +216 71496 066; Fax: +216 71391 166, Email: chokri.khaldi@esstt.rnu.tn (C. Khaldi).

$\ddagger$ formerly ESSTT
} 


\begin{abstract}
For the purpose of lowering the cost of metal hydride electrode, the $\mathrm{La}$ of $\mathrm{LaY}_{2} \mathrm{Ni}_{9}$ electrode was replaced by $\mathrm{Ce}$. The electrochemical performances of the $\mathrm{CeY}_{2} \mathrm{Ni}_{9}$ negative electrode, at a room and different temperatures, were compared with the parent alloy $\mathrm{LaY}_{2} \mathrm{Ni}_{9}$. At room temperature during a long cycling, the evolution of the electrochemical capacity; the diffusivity indicator $\left(\frac{D_{\mathrm{H}}}{a^{2}}\right)$, the exchange current density, and the equilibrium potential were determined. At different temperatures, the electrochemical characterization of this alloy allowed the estimation of the enthalpy, the entropy, and the activation energy of the hydride formation. The evolution of the high-rate dischargeability was also evaluated at different temperatures.
\end{abstract}

Compared with, the parent $\mathrm{LaY}_{2} \mathrm{Ni}_{9}$ alloy, $\mathrm{CeY}_{2} \mathrm{Ni}_{9}$ exhibits an easy activation and a good reaction reversibility. This alloy also conserves a good lifetime during a long term cycling. A lower activation energy determined for this alloy corresponds to an easy absorption of hydrogen into this new alloy.

Key words: Electrochemical properties, Hydrogen reactions, Activation energy, High rate discharge ability, enthalpy and entropy formation 


\section{Introduction}

Because of the dramatic environmental impact due to the greenhouse gas emission and to the limited fossil fuel sources, the research for alternative clean fuels is becoming increasingly important. Hydrogen is identified as a future clean energy carrier. However, the use of hydrogen as an energy carrier requires solutions for several problems such as hindering $\mathrm{CO}_{2}$ emission during its production, considering its storage, transportation, and safety issues. For a safe hydrogen storage, the use of metal as hydrides and related materials constitute a vast research area [1]. Such materials are also employed in rechargeable batteries which are more and more commercialized due to the increasing demand of electronic equipment and tools such as laptops, cameras, lighting units, and telecommunication systems [2,3]. The Ni-MH battery represents one of the greatest segments of this market thanks to its high energy density and environmentally friendly characteristics [4-9]. But recently, this type of battery is encountering a serious competition from Li-ion batteries and other advanced secondary batteries [10-12]. It is thus crucial to reduce the production cost and improve the specific power of Ni-MH batteries to enhance their competition and extend their application in highpower fields such as hybrid electric vehicles, power tools, etc...

Since the electricity is stored as hydrogen in metal hydrides, electrical and hydrogen storage properties are intimately linked to each other [13]. The battery characteristics can thus be specified in terms of their hydrogen storage capacity, hydride stability, and equilibrium pressure during hydride phase transformation. These properties can then be evaluated from pressure-composition-temperature (PCT) isotherms, which describe the dependence of the hydrogen equilibrium pressure on the amount of hydrogen absorbed or incorporated into the hydrogen storage material at various temperatures $[14,15]$. The performance of metal hydride electrodes is dictated also by the kinetics of the redox reactions occurring at the electrodeelectrolyte interface during the hydrogen absorption and desorption [16,17]. Several electro- 
analytical techniques estimate these kinetic parameters at room temperature [18-23]. However, electric vehicle and hybrid electric vehicle applications require fast chargedischarge and high-rate capability, inducing in internal heat generation. An excess of temperature increase will be detrimental to the redox reactions, the charge acceptance, the specific capacity, and the battery life cycle [24-27]. External heating or cooling will also affect the battery performance and therefore require a proper thermal management. For the electric vehicle applications, the $\mathrm{Ni}-\mathrm{MH}$ battery will operate in a wide temperature range, i.e. 0-60 ${ }^{\circ} \mathrm{C}$. Thus, the study of the electrode kinetics of the MH electrode as a function of temperature is of great importance [28-31].

With respect to the recent increasing demand for a higher performance of secondary batteries and for an environmental protection, nickel-metal hydride battery, using $\mathrm{AB}_{5}$-type hydrogen storage alloy as its negative material, in particular $\mathrm{LaNi}_{5}$ parent compound, is very convenient due to of its clean characteristic and its high performance [32-44]. However, the high cost of $\mathrm{AB}_{5}$-type alloys slows down its commercialization. To solve the cost problem, many researchers investigate extensively the partial replacement of $\mathrm{La}$ by $\mathrm{Ce}, \mathrm{Nd}, \mathrm{Pr}, \mathrm{Mg}, \mathrm{Ca}, \mathrm{Li}$, and $\mathrm{Ni}$ with $\mathrm{Sn}, \mathrm{Fe}, \mathrm{Al}$, etc. [45-49], the partial substitution of $\mathrm{Ce}$ for $\mathrm{La}$ was proved to be effective. Tan et al. [50] studied the performances of $\mathrm{La}_{1-x} \mathrm{Ce}_{x} \mathrm{Ni}_{5}$ alloys by powder microelectrode, and reported that the partial substitution of La with Ce could improve discharge potential of $\mathrm{La}_{1-x} \mathrm{Ce}_{x} \mathrm{Ni}_{5}$ electrode, the electron transfer reaction on the electrode surface, and the hydrogen diffusion coefficient in the bulk of the electrode.

Ye et al. [51] pointed out that the increase in Ce and decrease in La content improved the high-rate capability of $\mathrm{ReNi}_{3.55} \mathrm{Co}_{0.75} \mathrm{Mn}_{0.40} \mathrm{Al}_{0.30}$ alloys, and ascribed the improvement of the high-rate dischargeability (HRD) to the lower hydride stability. Besides, the La-Mg-Ni system hydrogen storage alloys were extensively studied as one of the new type negative electrode candidates for $\mathrm{AB}_{5}$-type alloys due to their larger discharge capability [52-57]. 
For example, Kohno et al. [58] concluded that $\mathrm{La}_{0.7} \mathrm{Mg}_{0.3} \mathrm{Ni}_{2.8} \mathrm{Co}_{0.5}$ electrode exhibits a large discharge capacitance $\left(0.41 \mathrm{Ah}^{-1}\right)$ and a good cyclic life time during 30 charge/discharge cycles. The main drawback for La-Mg-Ni system alloys to field application is their poor life cycle. Consequently, the improvement of the life cycle of La-Mg-Ni system alloys through substituting La with Ce [59-63] was investigated. Separate substitution of Ce for La induces actually the increase in hydrogen absorption/desorption plateau pressure, improved the life cycling, HRD and the exchange current density $\left(I_{0}\right)[64,63]$ but cannot solve unfortunately the poor life cycle thoroughly. This weakness is likely to be due to ignoring the critical effect of $\mathrm{Mg}$ in La-Mg-Ni system alloys, since $\mathrm{Mg}$ spoils the cyclic stability of the alloy electrodes in aqueous $\mathrm{KOH}$ medium.

A recent investigation of the $\mathrm{R}-\mathrm{Mg}-\mathrm{Ni}$ system revealed a new series of ternary alloys of general formula $\mathrm{RMg}_{2} \mathrm{Ni}_{9}(\mathrm{R}=$ rare earth or $\mathrm{Ca}$ element $)$ [65-69], which showed an intergrowth of $\mathrm{MgNi}_{2}$ and $\mathrm{RNi}_{5}$ layers. However these new compounds are not adapted to the electrochemical application from the thermodynamic point of view.

To overcome this problem, recent interest shifted towards the La-Y-Ni ternary system, such as $\mathrm{RY}_{2} \mathrm{Ni}_{9}(\mathrm{R}=\mathrm{La}, \mathrm{Ce})$. In general, the $\mathrm{CeY}_{2} \mathrm{Ni}_{9}$ compound adopts a rhombohedral structure derived from the PuNi3-type one ( $R-3 m$ space group), and it can be described as the intergrowth of $\mathrm{LaNi}_{5}$ (Haucke phase) and $\mathrm{YNi}_{2}$ (Laves phase).

The aim of the present work is to study the electrochemical properties of the $\mathrm{CeY}_{2} \mathrm{Ni}_{9}$ alloy, used as an anode in nickel-metal hydride batteries, at room and at different temperatures. A comparative study will be carried out to compare the results obtained by this alloy with those of the $\mathrm{LaY}_{2} \mathrm{Ni}_{9}$ parent alloy [70] and therefore evaluate the effect of the substitution of La by Ce on the electrochemical properties. 


\section{Experimental conditions}

\section{Material synthesis}

The $\mathrm{CeY}_{2} \mathrm{Ni}_{9}$ alloy was prepared by induction melting of the pure elements followed by an appropriate annealing to ensure a good homogeneity. The ingot alloy was grounded mechanically and sieved (to less than $63 \mu \mathrm{m}$ ) in a glove box under argon atmosphere [71]. The "latex" technology was used for the electrode preparation [72]. Ninety percent of the alloy powder was mixed with $5 \%$ of a black carbon to obtain a good conductivity, and $5 \%$ of polytetrafluoroethylene (PTFE). Then, this powder was rolled to yield a rubber-like sheet of about $0.3 \mathrm{~mm}$ thick. Two pieces of $0.5 \mathrm{~cm}^{2}$ of this latex were pressed on each side of a nickel grid, playing the role of a current collector [73]. This assembly forms the negative electrode of Ni-MH battery. The geometrical electrode surface area in contact with the electrolyte is thus $1 \mathrm{~cm}^{2}$ and weighs about $50 \mathrm{mg}$.

\section{Electrochemical characterization}

All the electrochemical measurements were performed, at a room temperature or at different temperatures $\left(30,40,50,60\right.$, and $\left.70{ }^{\circ} \mathrm{C}\right)$, in a conventional three-electrode cell with a BioLogic's potentiostat-galvanost, EC-Lab ${ }^{\circledR}$ V10.12. A nickel mesh and a Hg/HgO electrode were used as a counter and a reference electrode, respectively. The electrolyte was a $1 \mathrm{M}$ $\mathrm{KOH}$ solution stirred by a continuous flow of argon through the cell.

The experimental procedures used were as follows:

An activation of the $\mathrm{CeY}_{2} \mathrm{Ni}_{9}$ electrode and a long term cycling were carried out by galvanostatic mode at $\mathrm{C} / 10$ rate. Charging up to $50 \%$ overcharge to ensure complete charging and discharging to the cut off voltage $E=-0.6 \mathrm{~V}$ vs. $\mathrm{Hg} / \mathrm{HgO}$. The nominal capacitance $\mathrm{C}$, expressed by $\mathrm{mAh} \mathrm{g}^{-1}$, was determined by the following expression: 


$$
C=\frac{x F}{3.6 M}
$$

Wherein $F$ is the Faraday $\left(96,487 \mathrm{C} \mathrm{mol}^{-1}\right), M$ the molar mass of the alloy $\left(846.72 \mathrm{~g} \mathrm{~mol}^{-1}\right)$, and $x$ is the number of hydrogen atoms per alloy formula measured by solid-gas method $(7 \mathrm{H}$ $\left.\mathrm{mol}^{-1}\right) . C$ is thus calculated to be equal to $0.2216 \mathrm{Ah} \mathrm{g}^{-1}$.

The constant potential discharge (CPD) at $-0.6 \mathrm{~V}$ vs. $\mathrm{Hg} / \mathrm{HgO}$ was applied after each cycle at $\mathrm{C} / 10$ rate using a chronoamperometry method.

These experiments were followed by the cyclic voltametry $(\mathrm{CV})$ at a scan rate of $1 \mathrm{mV} \mathrm{s}$ from $-1.20 \mathrm{~V}$ to $-0.60 \mathrm{~V}$ vs. $\mathrm{Hg} / \mathrm{HgO}$ to estimate the exchange current density $I_{0}$ and at the potential $E_{0}$ zero overall current in $1 \mathrm{M} \mathrm{KOH}$ solution.

The pressure-composition isotherms $(\mathrm{P}-\mathrm{C}-\mathrm{T})$ curves at different temperatures were electrochemically obtained. The electrode was first fully charged at very low rate, $\mathrm{C} / 30$ regime with $50 \%$ overloads ( $45 \mathrm{~h}$ charging), and then the discharged at a $\mathrm{C} / 30$ rate at a current of $7.4 \mathrm{~mA} \mathrm{~g}^{-1}$ for $1 \mathrm{~h}$, followed by a stabilization period of $2 \mathrm{~h}$ before the equilibrium potential $(E)$ was recorded. Then the discharge and potential stabilization procedure was repeated until the electrodes reached the cut-off potential of $-0.6 \mathrm{~V}$ vs. $\mathrm{Hg} / \mathrm{HgO}$.

\section{Results and discussion}

Electrochemical proprieties at room temperature

\section{Annealing conditions and characterization results}

Table 1 displays the results of the metallographic examination, the electron probe microanalysis (EPMA), and the structure characterization by X-ray diffraction (XRD) of this alloy together with the parent alloy $\mathrm{LaY}_{2} \mathrm{Ni}_{9}$. The structural characterization shows that $\mathrm{CeY}_{2} \mathrm{Ni}_{9}$ is indexed in the rhombohedral cell of PuNi3 type belonging to the $\mathrm{R}-3 \mathrm{~m}$ (166) space group $(Z=3)$. 
Table 1. Annealing conditions and characterization results of the $\mathrm{CeY}_{2} \mathrm{Ni}_{9}$ and $\mathrm{LaY}_{2} \mathrm{Ni}_{9}$

\begin{tabular}{ccccccc}
\hline & & & & \multicolumn{3}{c}{ XRD analysis (cell } \\
Alloy & Space & Annealing & & \multicolumn{3}{c}{ parameters and volume) } \\
& group & temperature & EPMA analysis & \multicolumn{2}{c}{ parny } \\
\cline { 3 - 7 } & & & & $a(\AA)$ & $c(\AA)$ & $V\left(\AA^{3}\right)$ \\
\hline $\mathrm{LaY}_{2} \mathrm{Ni}_{9}[39]$ & $\mathrm{R}-3 \mathrm{~m}$ & $750{ }^{\circ} \mathrm{C}$ & $\mathrm{La}_{1.05} \mathrm{Y}_{1.98} \mathrm{Ni}_{8.97}$ & 5.034 & 24.507 & 537.9 \\
\hline $\mathrm{CeY}_{2} \mathrm{Ni}_{9}$ & $\mathrm{R}-3 \mathrm{~m}$ & $750{ }^{\circ} \mathrm{C}$ & $\mathrm{Ce}_{1.04} \mathrm{Y}_{1.93} \mathrm{Ni}_{9.02}$ & 4.986 & 24.658 & 530.9 \\
\hline
\end{tabular}

Activation capability and cycling stability

The activation capability, which is an important property for the practical application of the Ni-MH battery, was characterized by the number of charge-discharge cycles required for attaining the greatest discharge capacity through a charge-discharge cycle at a constant current density. The less is the activation cycle number, the better is the activation performance.

Fig. 1a and Fig. 1b show the electrochemical discharge capacity, the half charge and discharge potential curves, respectively, during the first activation cycles of the $\mathrm{CeY}_{2} \mathrm{Ni}_{9}$ electrode at $\mathrm{C} / 10$ rate and at room temperature.

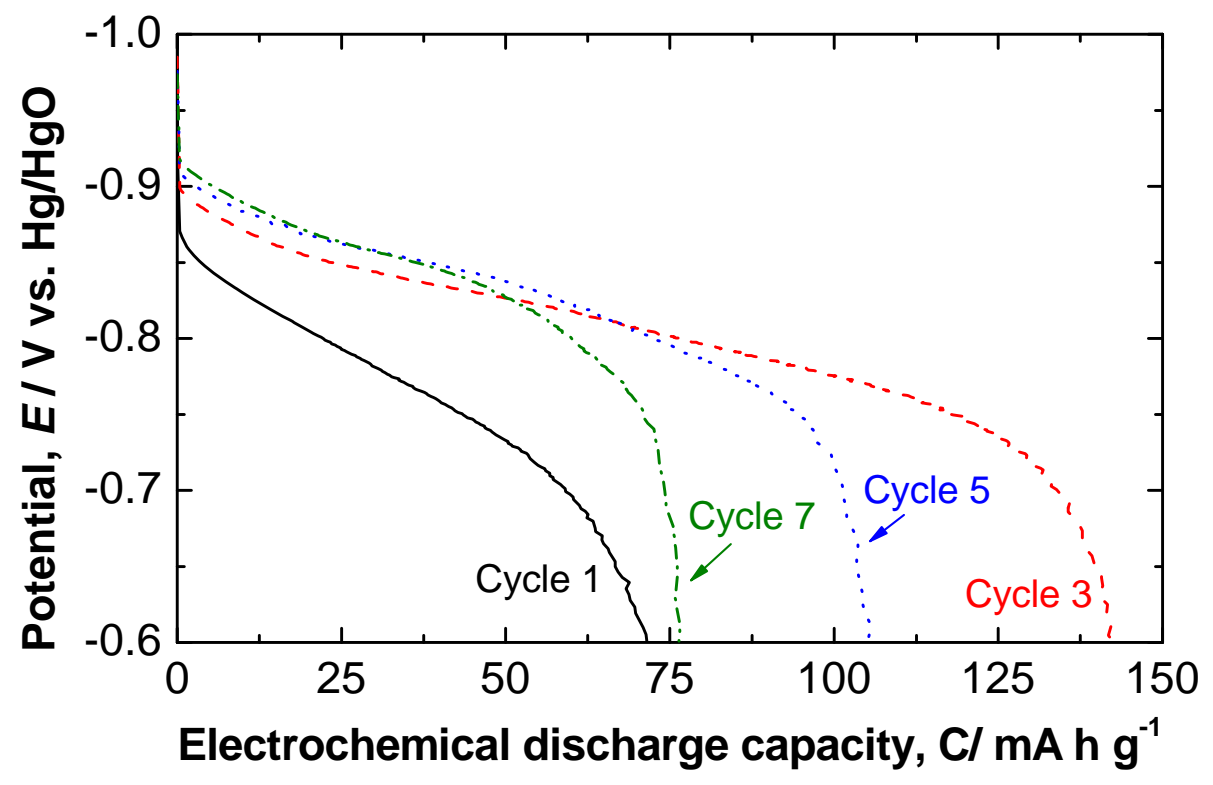


Fig. 1a. Discharge curves of the $\mathrm{CeY}_{2} \mathrm{Ni}_{9}$ electrode, during the first activation cycles, at $\mathrm{C} / 10$ rate and at room temperature.

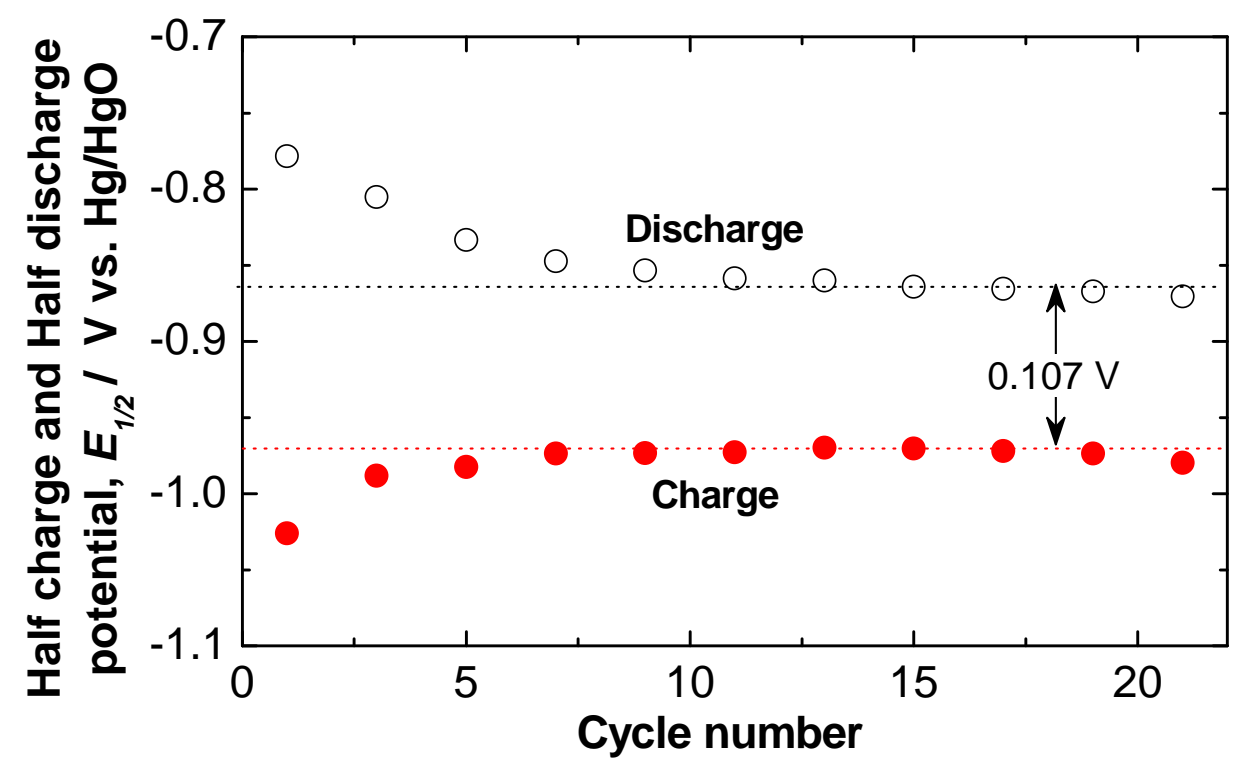

Fig. 1b. Half charge and half discharge potentials of the $\mathrm{CeY}_{2} \mathrm{Ni}_{9}$ electrode, during the first activation cycles at the $\mathrm{C} / 10$ rate and at room temperature.

These results show that the $\mathrm{CeY}_{2} \mathrm{Ni}_{9}$ electrode possesses an excellent activation capability and can be fully activated within three cycles, thus being attractive in practical applications. Indeed, at the first cycle, the capacity is $71.5 \mathrm{mAh} \mathrm{g}^{-1}$ and the half charge and discharge potential is -1.026 and $-0.778 \mathrm{~V}$, respectively. At the third cycle the discharge capacity reaches its maximum value of $143 \mathrm{mAh} \mathrm{g}^{-1}$ and the half charge and discharge become -0.988 and $-0.805 \mathrm{~V}$, respectively. Beyond the $4^{\text {th }}$ cycle, the half charge and discharge potentials become constant and the capacity discharge undergoes a progressive decrease.

The discharge capacity fades, after activation, may be related to the reduction of hydrogen interstitial sites in the active material of the working electrode due mainly to the $\mathrm{KOH}$ aggressive electrolyte.

The potential difference between the half charge and discharge potentials, reflecting the reversibility of the charge and discharge reaction, is proportional to the ratio (expressed as a 
percentage) between the energy removed from a battery during discharge compared with the energy used during charging to restore the original capacity. Also called the Coulombic Efficiency or charge acceptance.

The potential difference between the half charge and discharge potentials after activation is $0.107 \mathrm{~V}$. This value confirms that the $\mathrm{CeY}_{2} \mathrm{Ni}_{9}$ alloy presents a good reaction reversibility compared with other alloys, particularly the $\mathrm{LaY}_{2} \mathrm{Ni}_{9}$ parent alloy [70,74]. The total substitution of $\mathrm{La}$ by $\mathrm{Ce}$ in the $\mathrm{LaY}_{2} \mathrm{Ni}_{9}$ parent alloy enhances therefore the activation as well as the reversibility of the hydrogen absorption-desorption reaction in spite of the decreases of the discharge capacity (Table 2).

Table 2. Maximum discharge capacity, cycle number of activation and potential difference of both the $\mathrm{LaY}_{2} \mathrm{Ni}_{9}$ parent and the $\mathrm{CeY}_{2} \mathrm{Ni}_{9}$ mono-substituted alloys determined at $\mathrm{C} / 10$ rate and at room temperature.

\begin{tabular}{cccc}
\hline & $\begin{array}{c}\text { Maximum discharge capacity } \\
\left(\mathrm{mA} \mathrm{h} \mathrm{g}^{-1}\right)\end{array}$ & Cycle number for & Potential \\
& 258 & activation & difference $(\mathrm{mV})$ \\
\hline $\mathrm{LaY}_{2} \mathrm{Ni}_{9}[39]$ & 143 & 5 & 149 \\
\hline $\mathrm{CeY}_{2} \mathrm{Ni}_{9}$ & 3 & 107 \\
\hline
\end{tabular}

Cycling stability is an extremely important factor for the life service of hydrogen storage alloys. Fig. 2 depicts the cycling-lifetime curve of the $\mathrm{CeY}_{2} \mathrm{Ni}_{9}$ electrode for long cycling at $\mathrm{C} / 10$ rate at room temperature.

This curve reveals that this alloy can be fully activated within three charge/discharge cycles to achieve their maximum discharge capacity. After activation, the discharge capacity undergoes a sharp drop in the number of charge/discharge cycles. Indeed, at the third cycle, the discharge capacity is around $143 \mathrm{mAh} \mathrm{g}^{-1}$ about two third of the nominal capacity while at the $11^{\text {th }}$ cycle it decreases at around one half $\left(68.5 \mathrm{mAh} \mathrm{g}^{-1}\right)$ before stabilizing around this value 
up to 60 th cycle. Beyond the $60^{\text {th }}$ cycle the discharge capacity undergoes second slight decreases to Stabilize around $62 \mathrm{mAh} \mathrm{g}^{-1}$.

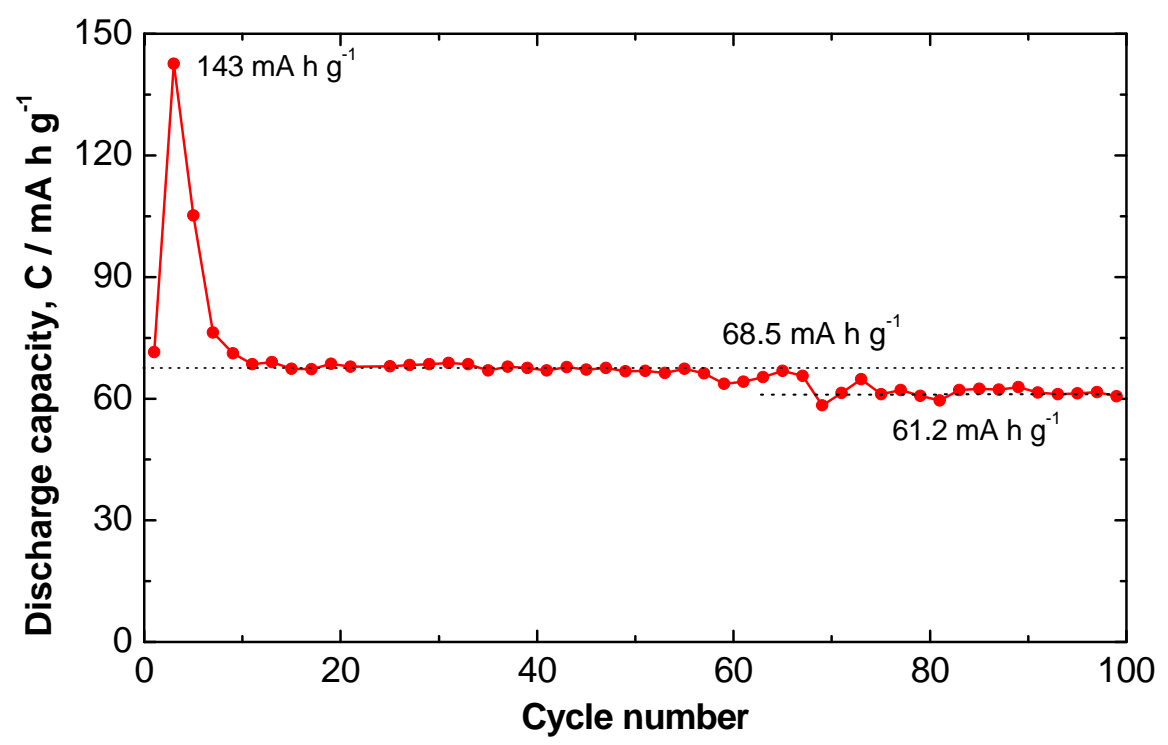

Fig. 2. Electrochemical discharge capacity with respect to cycle number of the $\mathrm{CeY}_{2} \mathrm{Ni}_{9}$ electrode at $\mathrm{C} / 10$ rate and at room temperature.

It can be noted that despite of the steep decrease of the discharge capacity after activation, this alloy conserves a good stability lifetime during a long cycling.

The cycling stability $S_{\mathrm{S}}$ of the alloy is characterized by the capacity conservation rate, which is defined as the ratio of discharge capacity after stabilization by the maximum discharge capacity:

$$
S_{\mathrm{S}}=\frac{100 C_{\mathrm{s}}}{C_{\max }}
$$

Where $C_{\max }$ is the maximum discharge capacity $\left(\mathrm{mAh} \mathrm{g}^{-1}\right)$ and $C_{\mathrm{s}}$ is the discharge capacity after stabilization $\left(\mathrm{mAh} \mathrm{g}^{-1}\right)$. The values of the discharge capacity conservation are $44-48 \%$ and $45 \%$ [70] for the $\mathrm{CeY}_{2} \mathrm{Ni}_{9}$ and $\mathrm{LaY}_{2} \mathrm{Ni}_{9}$ alloys, respectively. Though the total substitution 
of the $\mathrm{La}$ by $\mathrm{Ce}$ in the $\mathrm{LaY}_{2} \mathrm{Ni}_{9}$ parent alloy affects the discharge capacity, it maintains the capacity conservation.

The $\mathrm{CeY}_{2} \mathrm{Ni}_{9}$ material electrode shows more steeply sloping discharge profiles compared with those of the $\mathrm{LaY}_{2} \mathrm{Ni}_{9}$ material parent electrode. Despite, the difference of the voltage profiles and the relatively low capacity of the $\mathrm{CeY}_{2} \mathrm{Ni}_{9}$ alloy, the substitution of $\mathrm{La}$ by $\mathrm{Ce}$ does not deteriorates neither the stability of the alloy neither the cycling performance.

During the activation, the absorbed hydrogen in the alloy causes the fragmentation and the cracking of the electrode, leading to the increase of the active surface which accelerates the absorption and diffusion of hydrogen. After activation, the fresh surface of pulverized alloy particles is exposed directly to the agressive alkaline electrolyte, which will be oxidized thereafter leading to the deceleration of the kinetics absorption and consequently the decrease of discharge capacity [75]. Therefore, the fade of the discharge capacity after both the activation and 60 cycle may be explained by the corrosion and the dissolution phenomena of the active materials, respectively, engendering a reduction of the hydrogen interstitials sites.

\section{Redox parameters of the $\mathrm{CeY}_{2} \mathrm{Ni}_{9}$ alloy during a long cycling at room temperature}

The redox behavior of the $\mathrm{CeY}_{2} \mathrm{Ni}_{9}$ electrode was studied through the linear voltammetry technique during a long cycling at room temperature. This method consists of applying a linear potential scan rate of $1 \mathrm{mV} \mathrm{s}^{-1}$ on the $\mathrm{CeY}_{2} \mathrm{Ni}_{9}$ negative electrode after each cycle of charge and discharge at $\mathrm{C} / 10$ rate. The current was expressed as specific current, dividing the measured current $I$ by the mass of latex electrode.

Fig. 3a shows some experimental Tafel curves of the $\mathrm{CeY}_{2} \mathrm{Ni}_{9}$ electrode at $1 \mathrm{mV} \mathrm{s}^{-1}$ potential scan rate during a long cycling at room temperature.

It can be seen that both anodic and cathodic current increases with potential cycles up to ca. fortieth cycle. Beyond this cycle, the anodic process continues to increase whereas the process 
slows down. As a result, the Nersnt potential $E_{0}$ shifts towards a positive direction at the first cycles, then the opposite direction beyond the twentieth cycle. Besides, some lowering of the anodic current was observed for higher anodic polarization beyond $40^{\text {th }}$ cycle.

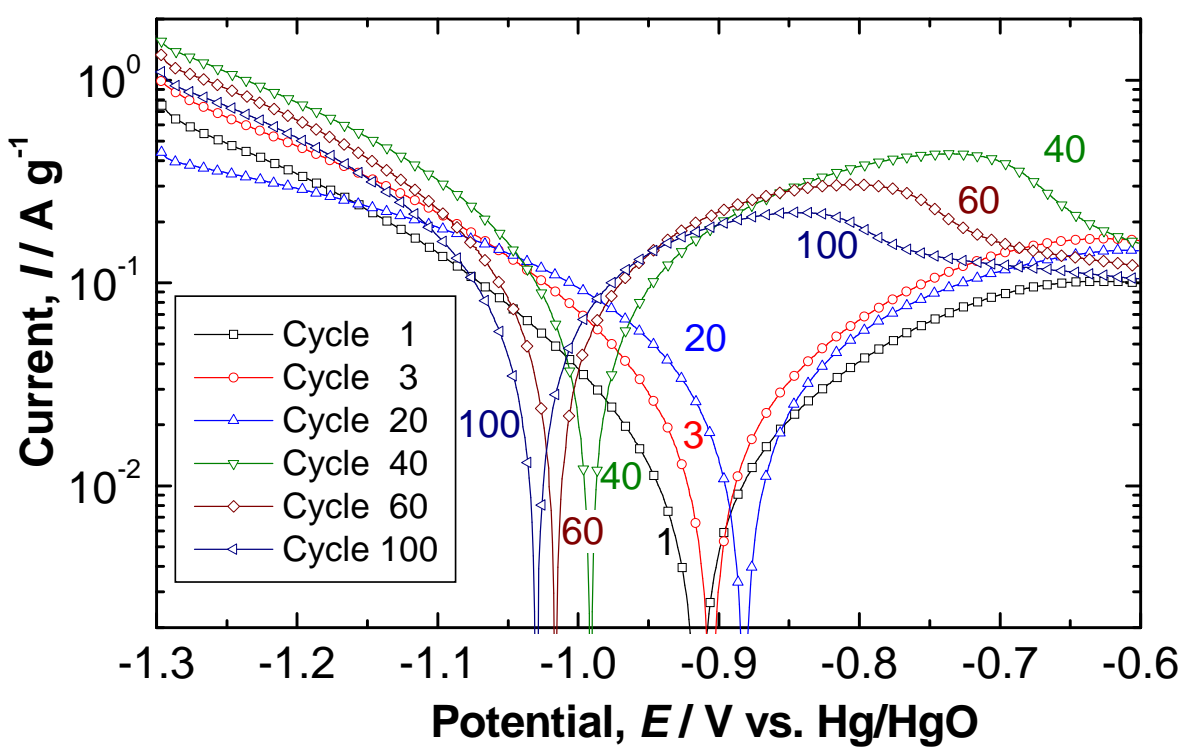

Fig. 3a. Experimental polarization curves of the $\mathrm{CeY}_{2} \mathrm{Ni}_{9}$ electrode at $1 \mathrm{mV} \mathrm{s}^{-1}$ potential scan rate, during a long cycling at room temperature.

Since the absorption-desorption of hydrogen is a reversible reaction, the application of ButlerVolmer equation, on the voltammograms obtained at different cycles, allows the kinetic parameters to be determined according to the following equation:

$$
I=I_{0} \cdot\left\{\exp \left[b_{\mathrm{a}} \cdot\left(E-E_{0}\right)\right]-\exp \left[b_{\mathrm{c}} \cdot\left(E-E_{0}\right)\right]\right\}
$$

Where, $I_{0}, b_{\mathrm{a}}, b_{\mathrm{c}}$ and $E_{0}$ stand respectively for the specific current density ( $\left.\mathrm{A} \mathrm{g}^{-1}\right)$, anodic and cathodic Tafel constant $\left(\mathrm{V}^{-1}\right)$, and the zero overall current potential (Nernst potential) (V). For a single electron transfer, the following relationship can be derived.

$$
b_{\mathrm{a}}-b_{\mathrm{c}}=\frac{F}{R T}\left(=38.9 \mathrm{~V}^{-1} \text { at } 25^{\circ} \mathrm{C}\right)
$$


Fig. $3 b$, for example, shows, the results of the regression calculation according to Equations (3) and (4) for the polarization curve obtained at the third activation charge and discharge step, i.e. when the electrode activation process is achieved. The results around $E_{0} \pm 30 \mathrm{mV}$ were used for the regression calculation to remain close to the redox potential and also to avoid a significant ohmic drop.

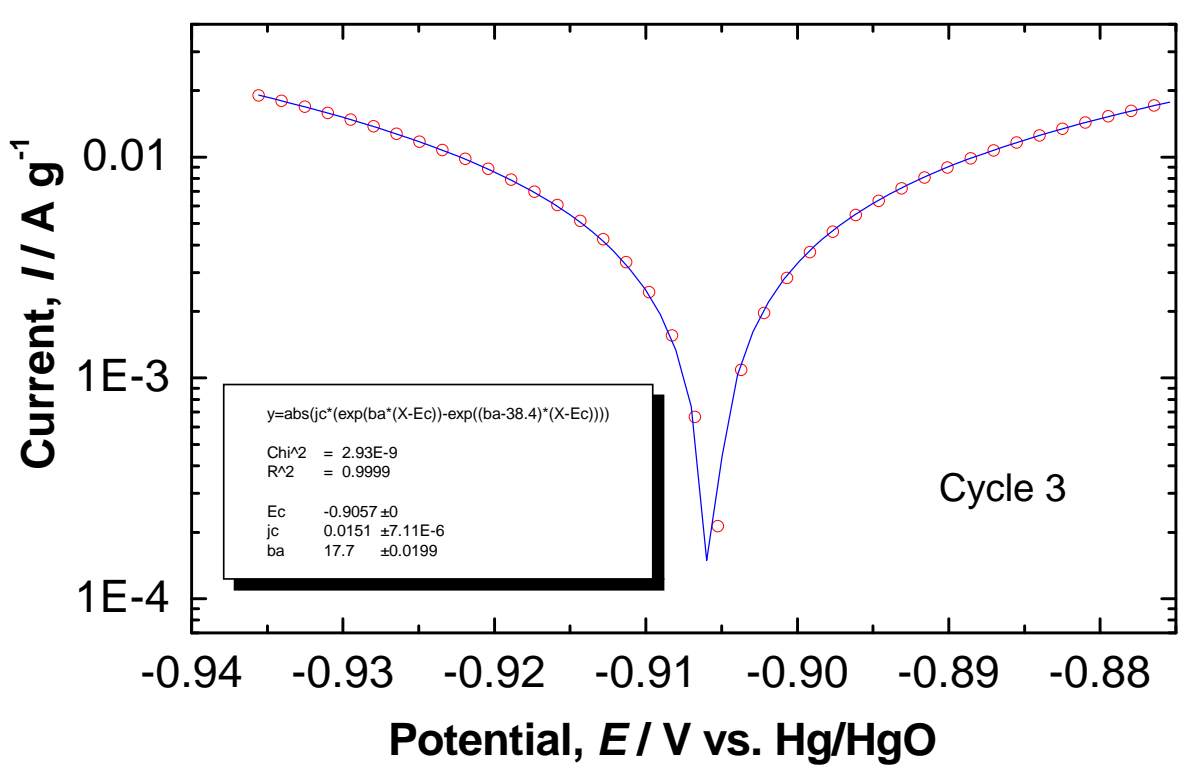

Fig. 3b. Comparison of experimental (symbol) and fitted data (solid line) for $3^{\text {rd }}$ cycle (cf. Fig.

4). The results of regression calculation by Simplex method; $E_{0}=-0.9057 \pm 0.000\left(\mathrm{~V}_{\mathrm{Hg} / \mathrm{HgO}}\right)$,

$$
I_{0}=0.0151 \pm 7.11 \mathrm{E}^{-6} \mathrm{~A} \mathrm{~g}^{-1}, b_{a}=17.7 \pm 0.01 \mathrm{~V}^{-1}, \chi^{2}=2.9310^{-9}, R^{2}=0.999
$$

Fig. $3 \mathrm{~b}$ shows a good agreement between experimental and calculated dada validating the electrode kinetics is actually reversible redox process of absorption-desorption of hydrogen, then the variation of $E_{0}$ and $I_{0}$ with respect of cycle number was evaluated.

Fig. 4 represents the evolution of $I_{0}$ and $E_{0}$ of the $\mathrm{CeY}_{2} \mathrm{Ni}_{9}$ electrode during a long cycling at room temperature. 


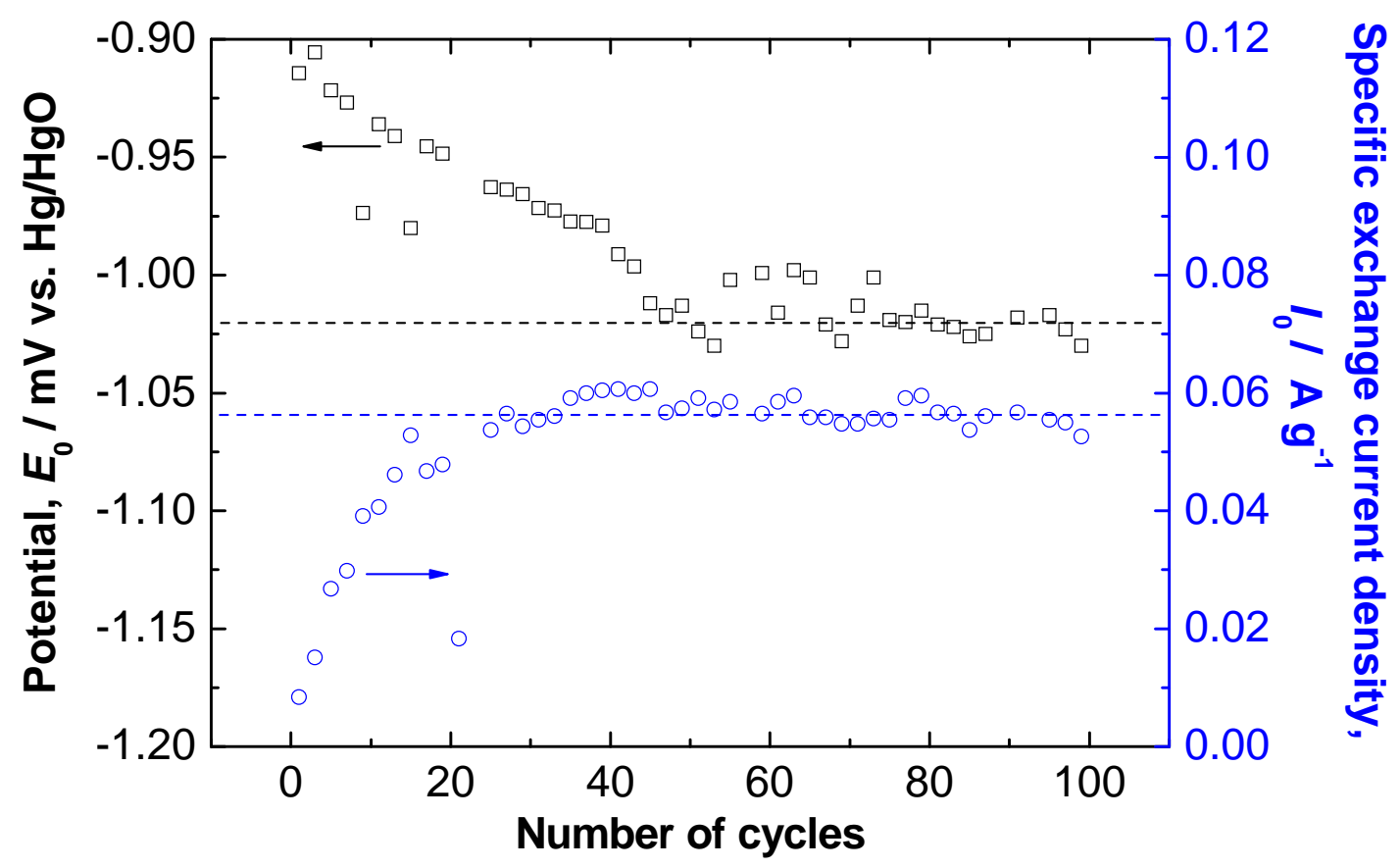

Fig. 4. Evolution of $I_{0}$ and $E_{0}$ of the $\mathrm{CeY}_{2} \mathrm{Ni}_{9}$ electrode during a long cycling at room temperature.

The potential $E_{0}$, during the first activation cycles, shifts towards a more cathodic direction even after the activation of the electrode is achieved, and reach the value of $-1.02 \mathrm{~V}$ at the fiftieth cycle. $E_{0}$ stays essentially constant above this cycle with some fluctuations.

The specific exchange current density, during the first cycles of activation and until fortieth cycle, increases with the electrochemical cycling. After that, the exchange current density stabilizes at around $0.057 \mathrm{~A} \mathrm{~g}^{-1}$. This result confirms a good behavior to the cycling test. This value is slightly lower than that of the $\mathrm{LaY}_{2} \mathrm{Ni}_{9}$ parent alloy, i.e. $0.079 \mathrm{~A} \mathrm{~g}^{-1}$. The substitution of La by Ce does not affect significantly the value of the specific exchange current density, despite the reduction of the discharge capacity after a long cycling. Indeed, the values of the discharge capacity and the exchange current density, during a long cycling, for the $\mathrm{LaY}_{2} \mathrm{Ni}_{9}$ parent [70] and $\mathrm{CeY}_{2} \mathrm{Ni}_{9}$ mono-substituted alloys are $140 \mathrm{mAh} \mathrm{g}^{-1}, 0.079 \mathrm{~A} \mathrm{~g}^{-1}$ and $65 \mathrm{mAh}$ $\mathrm{g}^{-1}, 0.057 \mathrm{~A} \mathrm{~g}^{-1}$, respectively. Table 3 summarizes some kinetic parameters of $\mathrm{LaY}_{2} \mathrm{Ni}_{9}$ and $\mathrm{CeY}_{2} \mathrm{Ni}_{9}$ electrodes. 
Table 3. Redox, kinetic and thermodynamic parameters of the $\mathrm{LaY}_{2} \mathrm{Ni}_{9}$ parent and the $\mathrm{CeY}_{2} \mathrm{Ni}_{9}$ mono-substituted alloys.

\begin{tabular}{|c|c|c|c|c|c|c|}
\hline & \multicolumn{2}{|c|}{ Redox parametres } & \multicolumn{2}{c|}{ Kinetic parameters } & \multicolumn{2}{c|}{ parameters } \\
& $I_{0}$ & $E_{0}$ & $E_{\mathrm{a}}$ & $D_{\mathrm{H}}$ & $\Delta H$ & $\Delta S$ \\
& $\left(\mathrm{~A} \mathrm{~g}^{-1}\right)$ & $(\mathrm{V})$ & $\left(\mathrm{kJ} \mathrm{mol}^{-1}\right)$ & $\left(\mathrm{cm}^{2} \mathrm{~s}^{-1}\right)$ & $\left(\mathrm{kJ} \mathrm{mol}^{-1}\right)$ & $\left(\mathrm{J} \mathrm{K}^{-1} \mathrm{~mol}^{-1}\right)$ \\
\hline $\mathrm{LaY}_{2} \mathrm{Ni}_{9}[39]$ & 0.079 & -0.993 & 14.84 & $10.2 \times 10^{-11}$ & -42.64 & 56.85 \\
\hline $\mathrm{CeY}_{2} \mathrm{Ni}_{9}$ & 0.057 & -1.021 & 10.78 & $6.8 \times 10^{-11}$ & -48.25 & 46.42 \\
\hline
\end{tabular}

Fig. 5 shows the variation of $b_{\mathrm{a}}$ of the $\mathrm{CeY}_{2} \mathrm{Ni}_{9}$ electrode during a long cycling at room temperature.

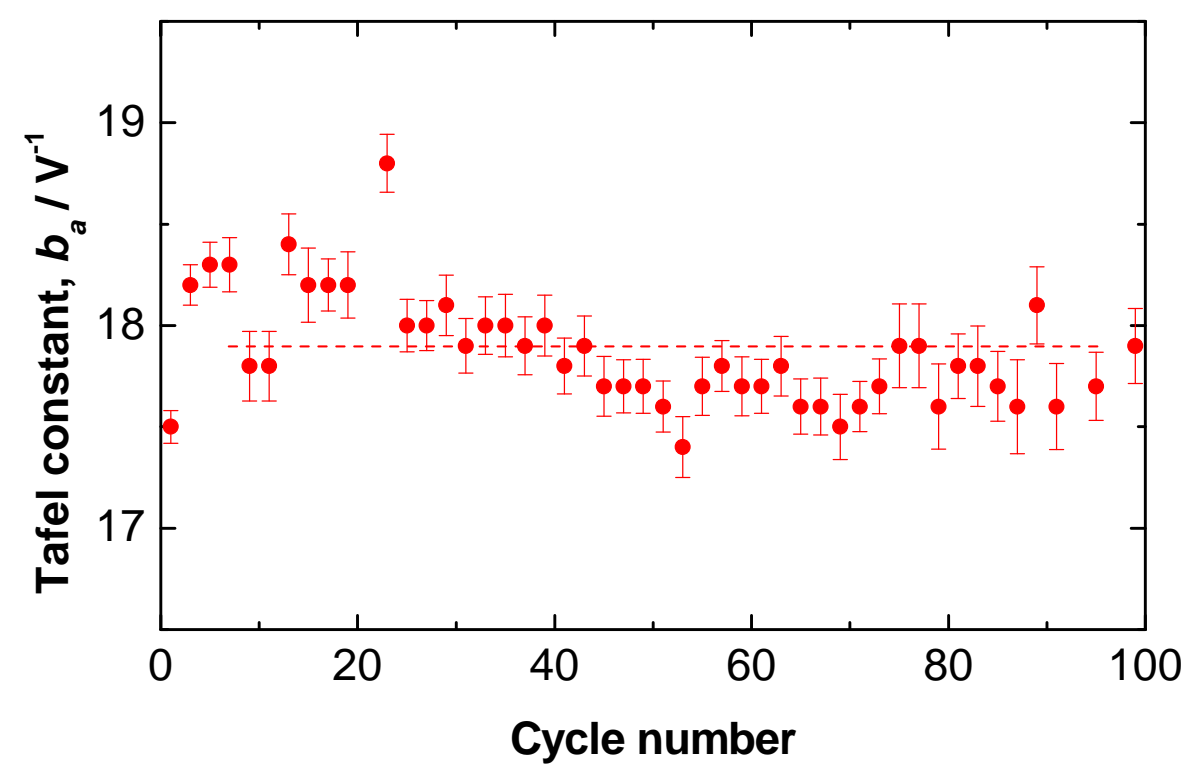

Fig. 5. Evolution of the Tafel constant for the anodic process with respect to cycle number (other conditions see in Fig 4).

As can be seen in Fig. 5, $b_{\mathrm{a}}$ remains essentially constant with the mean values of $17.9 \mathrm{~V}^{-1}$, that is, the Tafel coefficient equal to 0.46 . The redox process is almost symmetrical. 
The semi logarithmic plots of the chronoamperometic curve at $E=-0.6 \mathrm{~V}$ vs. $\mathrm{Hg} / \mathrm{HgO}$ of $\mathrm{CeY}_{2} \mathrm{Ni}_{9}$ electrode during cycling at room temperature show that the current-time responses can be divided into two time domains, in the short time region; the oxidation current of hydrogen rapidly declines due to the rapid consumption of hydrogen at the surface. However, for a longer time region, the current decreases more slowly and drops almost linearly with time. Since hydrogen is supplied from the bulk of the alloy at a rate proportional to the concentration gradient of hydrogen, the current density will be controlled by the diffusion of hydrogen in the second time region. Zheng et al. [76] reported that in a large anodic potential step test, after a long discharge time, the diffusion current varies according to the following equation:

$$
\log (I)=\log \left\{\frac{6 \cdot F \cdot D_{\mathrm{H}}}{d \cdot a^{2}}\left(C_{0}-C_{\mathrm{s}}\right)\right\}-\frac{\pi^{2} \cdot D_{H}}{2.303 \cdot a^{2}} \cdot t
$$

Wherein $D_{\mathrm{H}}$ is the hydrogen diffusion coefficient $\left(\mathrm{cm}^{2} \mathrm{~s}^{-1}\right), a$ is the radius of the spherical alloy particle $(\mathrm{cm}), I$ is the diffusion current density $\left(\mathrm{mA} \mathrm{g}^{-1}\right), C_{0}$ is the initial hydrogen concentration in the alloy bulk $\left.(\mathrm{mol} \mathrm{cm})^{-3}\right), C_{\mathrm{s}}$ is the hydrogen concentration of the alloy particles $\left(\mathrm{mol} \mathrm{cm}{ }^{-3}\right)$ at the surface, $F$ is the Faraday $\left(96487 \mathrm{C} \mathrm{mol}^{-1}\right), d$ the density of the hydrogen storage alloy $\left(\mathrm{g} \mathrm{cm}^{-3}\right)$, and $t$ the discharge time (s).

According to the Equation (5), knowing the slope of the linear region of the corresponding plots, $\frac{\mathrm{d}(\log (I))}{\mathrm{d} t}$, the ratio $\frac{D_{\mathrm{H}}}{a^{2}}=-\frac{2.303}{2} \frac{\mathrm{d}(\log (I))}{\mathrm{d} t}$ of the hydrogen storage electrode can be calculated, for each cycle.

Fig. 6 shows the evolution of the $\frac{D_{\mathrm{H}}}{a^{2}}$ ratio, as a function of the cycle number of $\mathrm{CeY}_{2} \mathrm{Ni}_{9}$ electrode. 


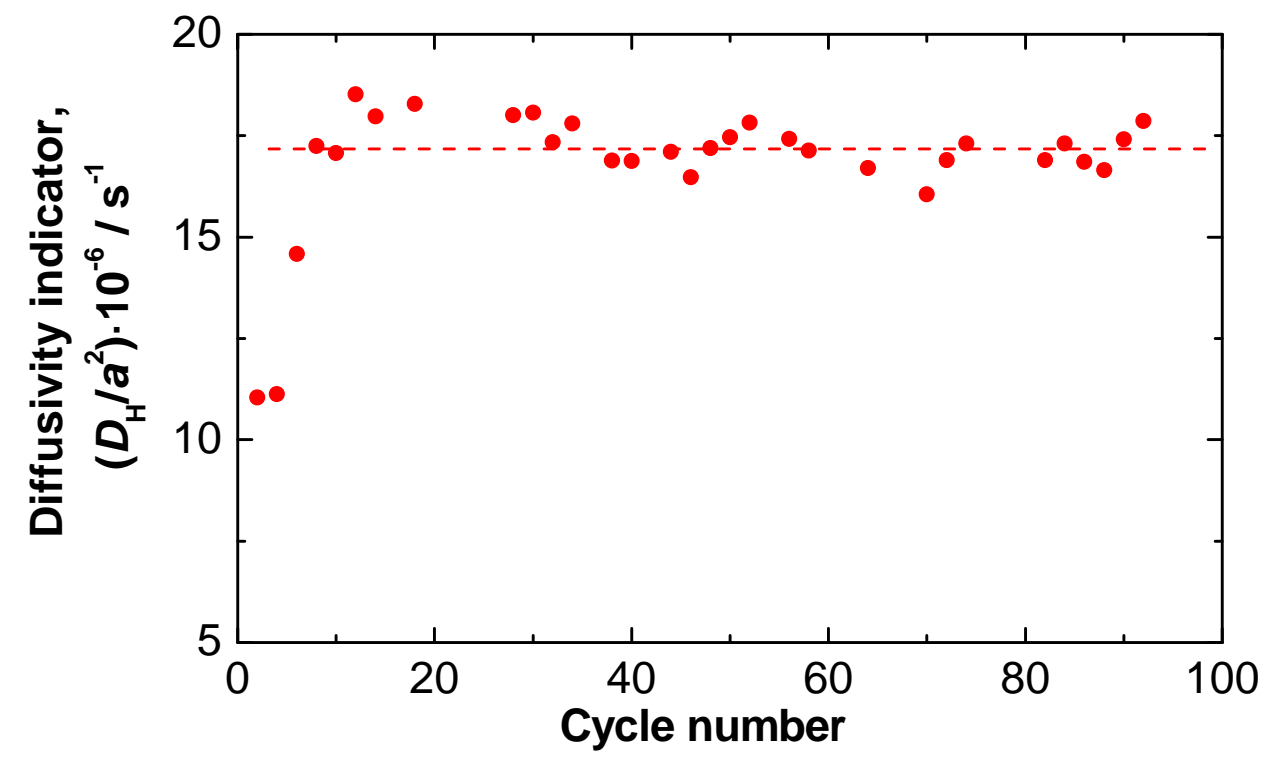

Fig. 6. Evolution of the diffusivity indicator $D_{\mathrm{H}} / a^{2}$ ratio during a long cycling at room temperature of $\mathrm{CeY}_{2} \mathrm{Ni}_{9}$ electrode.

The diffusivity indicator $\frac{D_{\mathrm{H}}}{a^{2}}$, the reciprocal of the diffusion time constant, undergoes a steep increase during the first cycles of the activation from $1110^{-6} \mathrm{~s}^{-1}$ at the first cycle to $18.510^{-6}$ $\mathrm{s}^{-1}$ at the twelfth cycle. Beyond the twenty-eighth cycle, this ratio fluctuates around $1710^{-6} \mathrm{~s}^{-1}$. With the grain size determined in the previous work [70], after electrochemical tests of a long cycling, the diffusion coefficient of the $\mathrm{CeY}_{2} \mathrm{Ni}_{9}$ mono-substituted electrode is estimated to be $6.810^{-11} \mathrm{~cm}^{2} \mathrm{~s}^{-1}$, which is slightly lower than that of the $\mathrm{LaY}_{2} \mathrm{Ni}_{9}$ parent electrode.

The good cycling as well as the activation properties are related to the evolution of the kinetic parameters such as the diffusion coefficient and the specific exchange current density. Indeed, despite the slight decrease of the kinetic parameter values during the long cycling, under the replacement effect of $\mathrm{La}$ by $\mathrm{Ce}$, a reduction in the number of activation cycles and an improvement of the cycling stability parameter are observed (Tables 2 and 3). This result is attributed to the positive effect of cerium on the stability of the electrode [50,51]. 
Electrochemical proprieties at different temperatures

\section{Effect of temperature on the electrode kinetics}

Temperature is one of the most determining parameters in electrode kinetic studies. It affects the physical-chemical and electrochemical hydrogen absorption/desorption reaction rates. Both the hydrogen absorption capability and the hydrogenation/dehydrogenation kinetics determine the performance of the metal hydride electrode.

Fig. 7 shows the Tafel plots of the $\mathrm{CeY}_{2} \mathrm{Ni}_{9}$ electrode, at different temperatures obtained at a scan rate of $1 \mathrm{mV} \mathrm{s}^{-1}$.

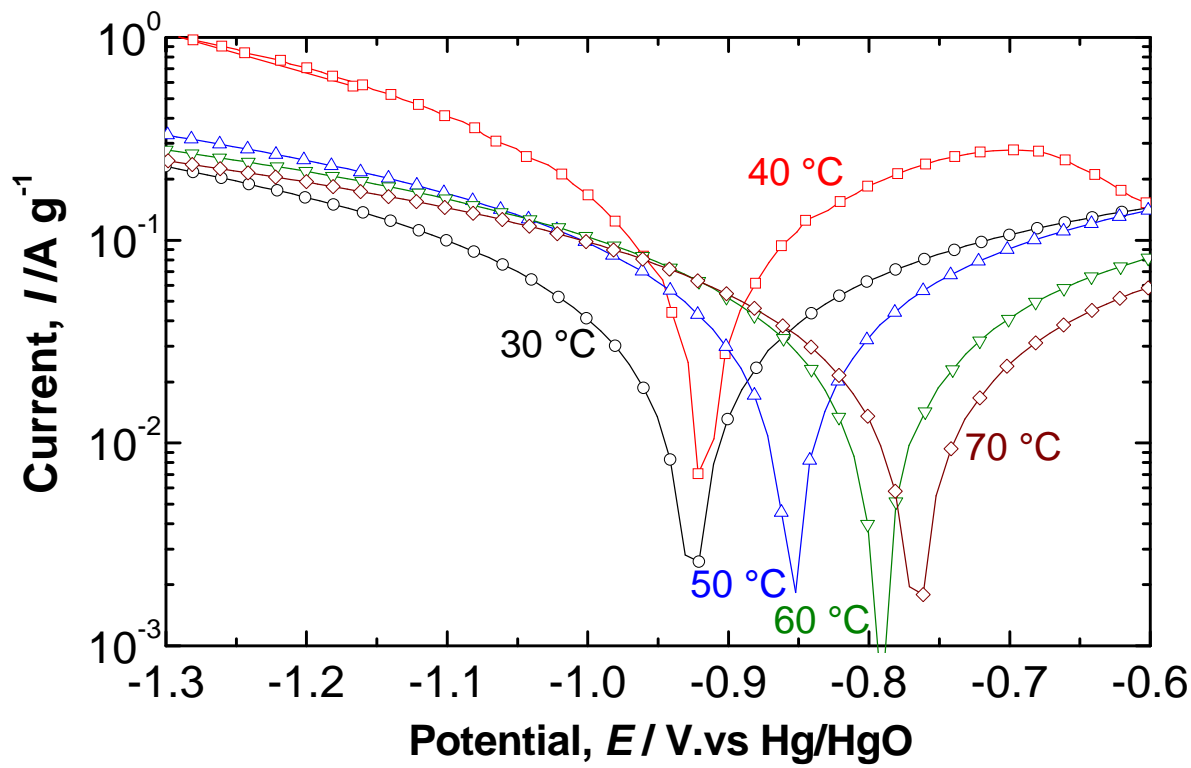

Fig. 7. Tafel plots of the $\mathrm{CeY}_{2} \mathrm{Ni}_{9}$ electrode, at $1 \mathrm{mV} \mathrm{s}^{-1}$ potential scan rate and at different temperatures.

$E_{0}$ shifts towards a more positive direction with the increase of the temperature. Both the anodic and cathodic specific currents increase when the temperature is augmented from $30{ }^{\circ} \mathrm{C}$ to $40{ }^{\circ} \mathrm{C}$. Beyond $40{ }^{\circ} \mathrm{C}$ both the cathodic and anodic current diminishes and the Tafel slope of the cathodic branch becomes greater with temperature increase.

$E_{0}$ and $I_{0}$ deduced from the Tafel curves at different temperatures are represented in Fig. 8. 


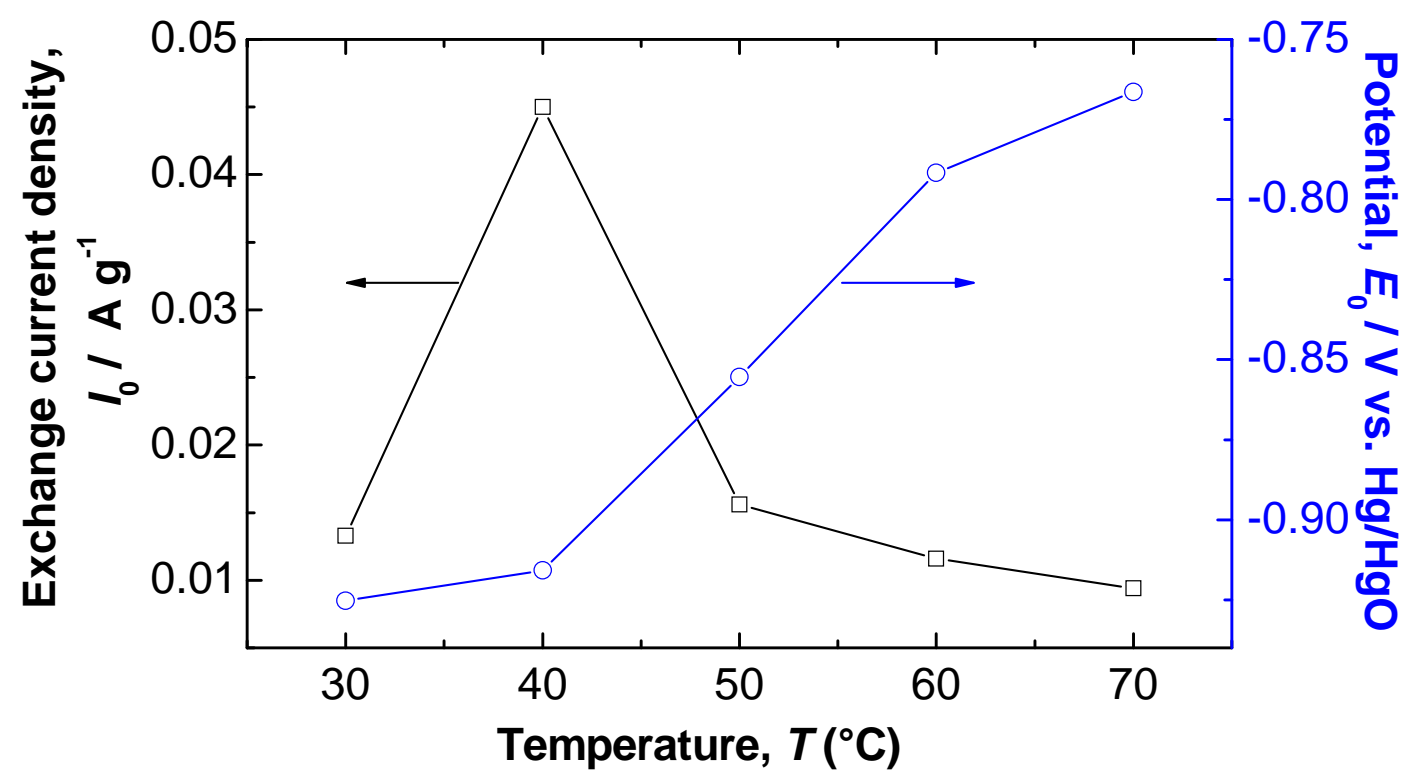

Fig. 8. Evolution of $E_{0}$ and $I_{0}$ of the $\mathrm{CeY}_{2} \mathrm{Ni}_{9}$ electrode at different temperature.

The higher the temperature is, the more positive the potential $E_{0}$ is in agreement with the Nernst equation. However, the Nernst equation predicts the standard potential shift of only 3.9 $\mathrm{mV}$ when the temperature rises from 30 to $70{ }^{\circ} \mathrm{C}$, no comparison with that observed experimentally. A much bigger change in the redox process will thus take place at the electrode process. However, these results displayed in Fig. 8 are in good agreement with those found for other $\mathrm{AB}_{5}$-type alloys [77, 78].

The exchange current density value increases by rising the temperature from $30{ }^{\circ} \mathrm{C}$ to $40{ }^{\circ} \mathrm{C}$; $13 \mathrm{~mA} \mathrm{~g}^{-1}$ and $45 \mathrm{~mA} \mathrm{~g}^{-1}$, respectively, for 30 and $40{ }^{\circ} \mathrm{C}$. This variation corroborates the previous work carried out on $\mathrm{AB}_{5}$-type alloys [79]. Beyond $40{ }^{\circ} \mathrm{C}$, the exchange current density undergoes a sharp drop to $50{ }^{\circ} \mathrm{C}$ then a gradual decrease and stabilization around 10 $\mathrm{mA} \mathrm{g}^{-1}$. This current decrease corresponds to that of the cathodic current, beyond this threshold temperature. The decrease of anodic and cathodic currents may be allocated to the formation of an oxide film on the surface of the electrode, thereby degrading the kinetic properties and reducing the active surface area. Thus, it is reasonable to consider the compromise of these antagonistic effects of temperature. 
The apparent activation energy $\left(E_{\mathrm{a}}\right)$ of the diffusion of hydrogen in the alloy bulk is the determining step when the hydrogen, close to the surface, is consumed. $E_{\mathrm{a}}$ can be determined by the Arrhenius equation:

$$
\ln \left(D_{\mathrm{H}}\right)=-\frac{E_{a}}{R \cdot T}+A
$$

Where $A$ is a constant and $T$ is the temperature $(\mathrm{K}), D_{\mathrm{H}}$ is the hydrogen diffusion coefficient calculated from the linear part of the chronoamperometric curves.

The $D_{\mathrm{H}}$ values found at different temperatures according to Equation (5) were used to plot the 1/T dependence of $\ln \left(D_{\mathrm{H}}\right)$ as shown in Fig. 9.

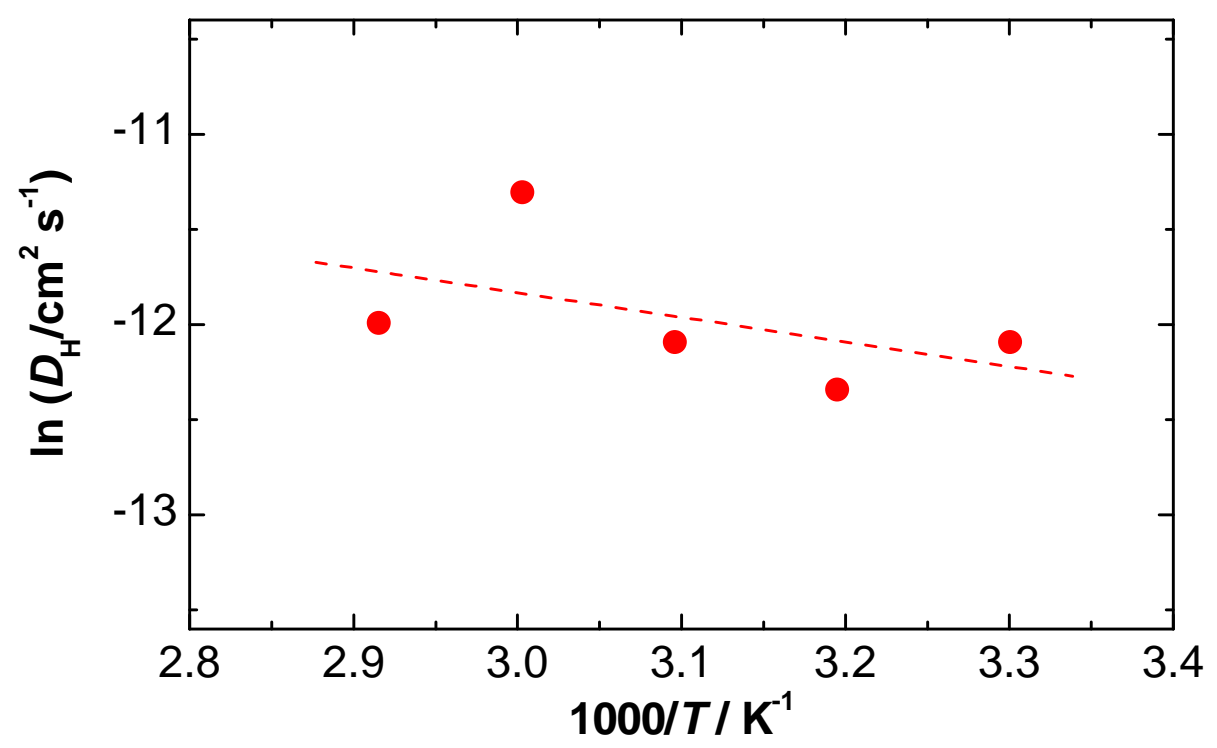

Fig. 9. The Arrhenius plot, $\ln \left(D_{\mathrm{H}}\right)$ vs. $1 / \mathrm{T}$ of the $\mathrm{CeY}_{2} \mathrm{Ni}_{9}$ electrode.

The straight line of $\ln \left(D_{\mathrm{H}}\right)$ vs. 1/T in Fig. 9 gives the apparent activation energy of $10.78 \mathrm{~kJ}$ $\mathrm{mol}^{-1}$. This value is lower than that found for the $\mathrm{LaY}_{2} \mathrm{Ni}_{9}$ parent alloy $\left(\sim 14.84 \mathrm{~kJ} \mathrm{~mol}^{-1}\right)$. The activation energy thus calculated is in agreement with the diffusion process. The difference 
observed between these two alloys shows the effect of substitution of La by Ce corresponding to the easy absorption of hydrogen into this Ce substituted alloy.

High-rate-dischargeability of the $\mathrm{CeY}_{2} \mathrm{Ni}_{9}$ alloy

High Rate Dischargeability (HRD) of the alloy electrodes is considered to be one of the important characteristics for the practical application in nickel metal hydride power batteries. Fig. 10 shows the relationship between $\mathrm{HRD}$ and the discharge current density of the $\mathrm{CeY}_{2} \mathrm{Ni}_{9}$ electrodes at different temperatures. The HRD, which characterizes mainly the kinetic of the metal hydride electrode, is calculated for each temperature by the following equation:

$\operatorname{HRD}(\%)=\frac{100 \cdot C \mathrm{i}}{C_{\max }}$

Where, $C_{\mathrm{i}}$ is the discharge capacity with a cut-off potential at $-0.6 \mathrm{~V}$ vs. $\mathrm{Hg} / \mathrm{HgO}$ for different discharge current density and $C_{\max }$ is the maximum discharge capacity for a given temperature.

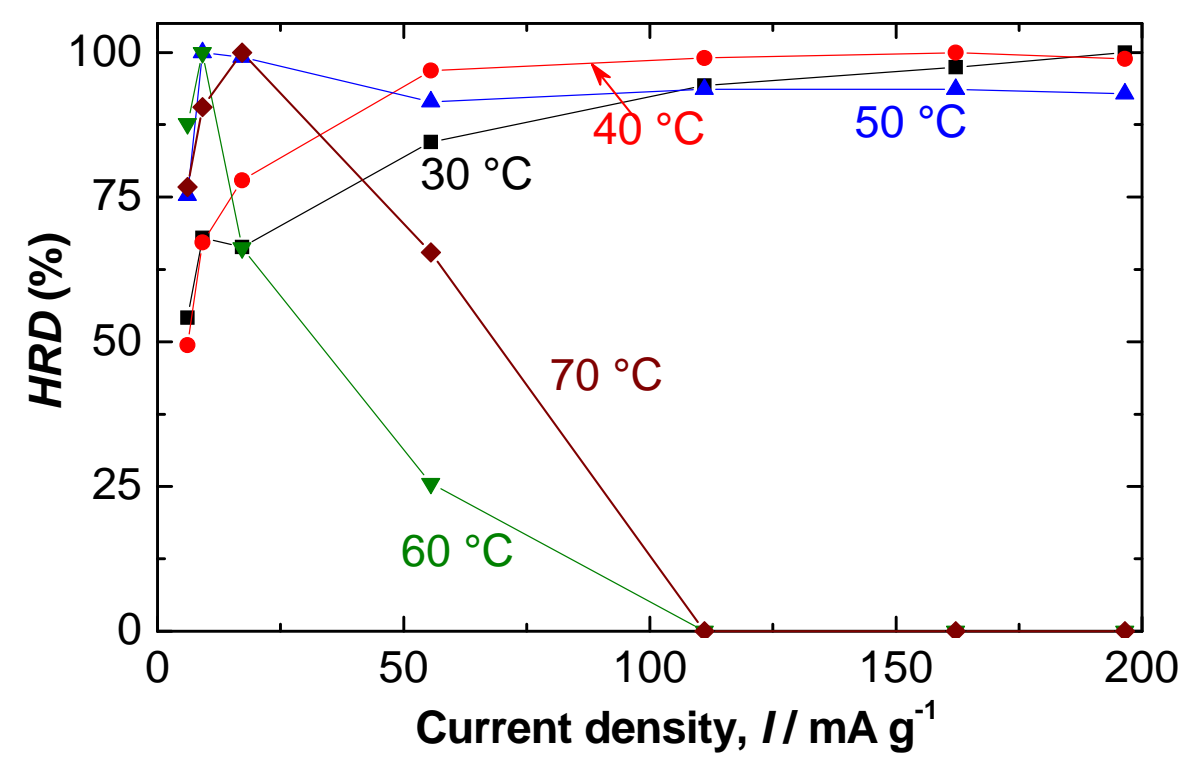

Fig. 10. High Rate Dischargeability $(H R D)$ in $\%$, of the $\mathrm{CeY}_{2} \mathrm{Ni}_{9}$ electrode with respect to discharge current density at different temperatures. 
It can be remarked that the HRD at low current density $\left(<10 \mathrm{~mA} \mathrm{~g}^{-1}\right)$ follows a monotonic variation with temperature; the HRD values at $10 \mathrm{~mA} \mathrm{~g}^{-1}$ evolved from $68 \%$ at $30{ }^{\circ} \mathrm{C}$ to $91 \%$ at $70{ }^{\circ} \mathrm{C}$. At a current density higher than $10 \mathrm{~mA} \mathrm{~g}^{-1}$, The $\mathrm{HRD}$ at 30,40 and $50{ }^{\circ} \mathrm{C}$, increases with temperature and tends to stabilize at $56 \mathrm{~mA} \mathrm{~g}^{-1}$ around a value greater than $90 \%$. Indeed, the HRD values are about 100, 99 and $93 \%$ at $200 \mathrm{~mA} \mathrm{~g}^{-1}$, respectively, for 30,40 and $50{ }^{\circ} \mathrm{C}$. The HRD at 60 and $70{ }^{\circ} \mathrm{C}$ undergoes a rapid decay and becomes close to zero at $110 \mathrm{~mA} \mathrm{~g}^{-1}$. These results are in a good agreement with the evolution of the electrode kinetics parameters at different temperatures.

The substitution of La by Ce improves the HRD at 40 and $50{ }^{\circ} \mathrm{C}$ but does not enhance it at 60 and $70{ }^{\circ} \mathrm{C}$, which is in a good agreement with the improvement of the other electrochemical kinetic properties.

The HRD of Ni-MH negative electrode is governed by the electrochemical kinetics of the charge-transfer reaction at the electrode/electrolyte interface and the hydrogen diffusion rate within the alloy bulk. They determine the exchange current density $\left(I_{0}\right)$ as well as in the hydrogen diffusion coefficient $\left(D_{\mathrm{H}}\right)$, which characterizes the mass transport properties of an alloy electrode [80].

\section{Pressure-Composition-Temperature curves of the $\mathrm{CeY}_{2} \mathrm{Ni}_{9}$ alloy}

Pressure-Composition-Temperature (PCT) curve is the isotherm of hydrogen pressure at equilibrium and hydrogen concentration of metal hydride during its reversible hydrogen absorption/desorption process.

The equivalence potential-pressure and electrochemical discharge capacity of solid-gas capacity allows us to draw the PCT isotherm curves [70]. These curves allow to evaluate the thermodynamic properties of hydrogen storage material [81-83]. 
The equivalence between the potential-pressure and the electrochemical discharge capacitysolid gas capacity, as explained previously [70], are expressed by the following equation:

$$
P_{\mathrm{H}_{2}}=\exp \left\{-\frac{2 \cdot F}{R \cdot T}(E+0.926)\right\}
$$

Fig. 11 shows the solid-gas isotherms, deducted from the equivalent electrochemical/solid-gas measurements, of the $\mathrm{CeY}_{2} \mathrm{Ni}_{9}$ alloy after activation at different temperatures according to Equation (8) and the PCT curves determined by successive discharges.

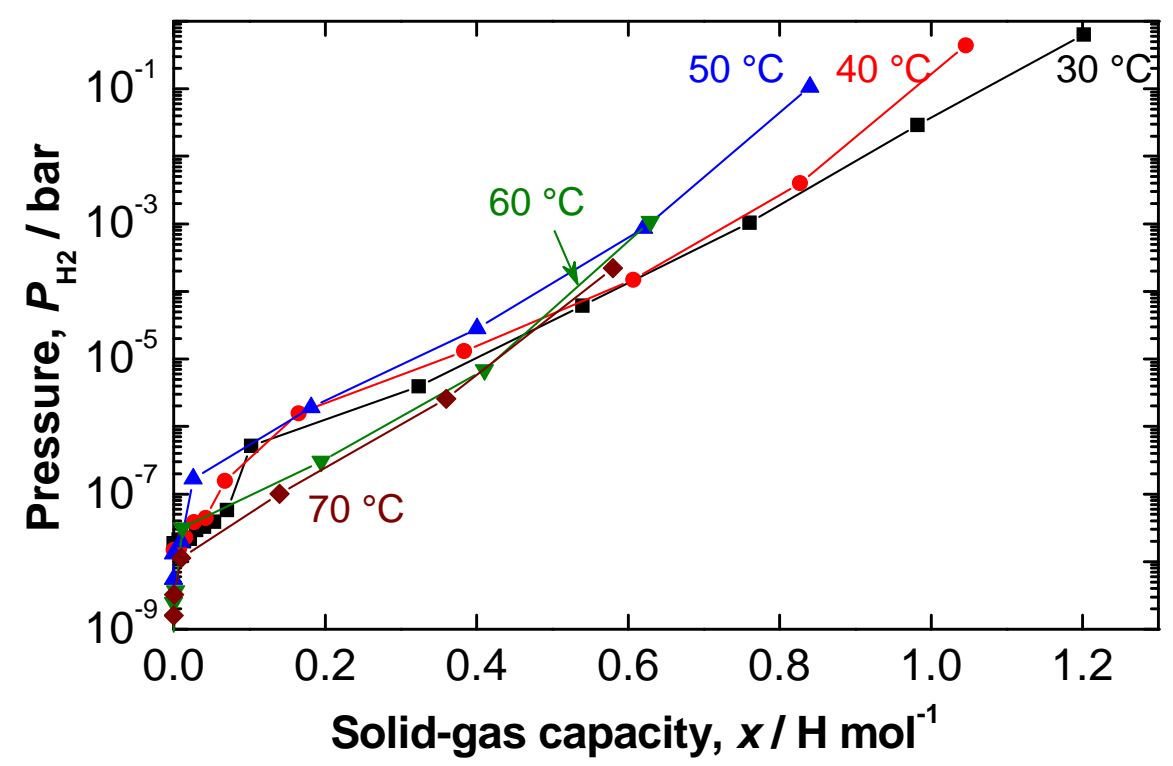

Fig. 11. Solid-gas isotherms deducted from the equivalent electrochemical/solid-gas measurements at different temperatures.

The isotherms obtained for the $\mathrm{CeY}_{2} \mathrm{Ni}_{9}$ mono-substituted alloy present the same features as those of the $\mathrm{LaY}_{2} \mathrm{Ni}_{9}$ parent alloy with the reduction of the hydrogen content. Indeed, the values of the hydrogen content at $30{ }^{\circ} \mathrm{C}$ for the $\mathrm{LaY}_{2} \mathrm{Ni}_{9}$ parent and $\mathrm{CeY}_{2} \mathrm{Ni}_{9}$ alloys are about 5.7 and $1.2 \mathrm{H} \mathrm{mol}^{-1}$, respectively.

The exploitation of these solid-gas isotherms provides access to the values of quasiequilibrium pressure and the solid-gas capacity for each temperature. From the Van't-Hoff 
curve, $\ln \left(P_{\mathrm{H}_{2}}\right)=\mathrm{f}\left(\frac{1000}{T}\right)$, shown in Fig. 12, the enthalpy and the entropy formation of the $\mathrm{CeY}_{2} \mathrm{Ni}_{9} \mathrm{H}_{\mathrm{x}}$ hydride are evaluated.

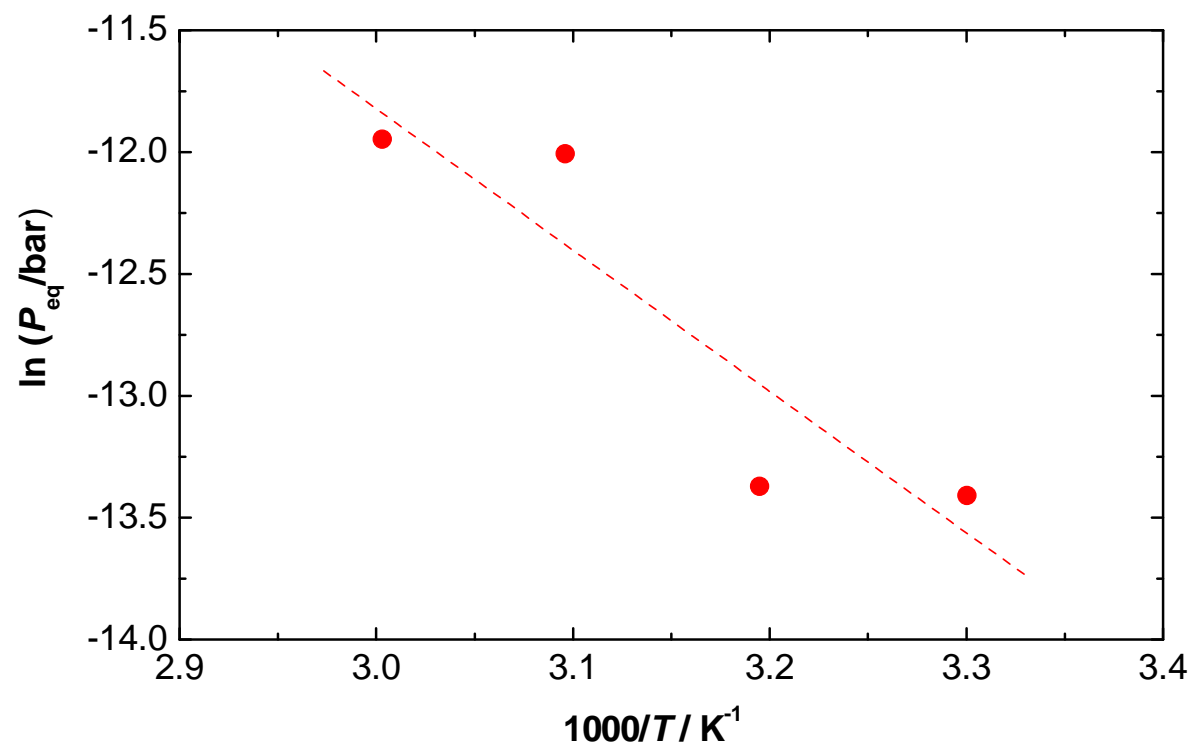

Fig. 12. Van't-Hoff plot, $\ln \left(P_{\text {eq }}\right)$ vs. $1 / T$, of the $\mathrm{CeY}_{2} \mathrm{Ni}_{9}$ electrode.

The enthalpy of the hydride formation is a determining parameter that serves for the assessment of the applicability as a hydrogen absorber of alloys in various utilizations. Kleperis et al. [84] stated that if the value of $\Delta H$ ranges between -25 and $-50 \mathrm{~kJ} \mathrm{~mol}^{-1}$, the alloy is a viable candidate for battery applications. Hong [85] got little lower values for the heat of the alloy hydride formation i.e. between -15 and $-40 \mathrm{~kJ} \mathrm{~mol}^{-1}$. A value higher than -15 $\mathrm{kJ} \mathrm{mol}^{-1}$ (lower than $15 \mathrm{~kJ} \mathrm{~mol}^{-1}$ in absolute value) indicates that the alloy is not sufficiently stable for charging at room temperature, whereas for a $\Delta H$ smaller than $-50 \mathrm{~kJ} \mathrm{~mol}^{-1}$, the alloy should be very stable for the discharge at room temperature. In practice, $\Delta H$ is an indication of the thermo-chemical stability of metal hydride electrodes. A high $\Delta H$ in absolute value would signify a high degree of stability of the hydride and low dissociation pressures, which means that a high temperature is required to decompose the alloy to release the hydrogen. 
The values of the enthalpy and the entropy formation of the $\mathrm{CeY}_{2} \mathrm{Ni}_{9} \mathrm{H}_{\mathrm{x}}$ hydride are about $48.3 \mathrm{~kJ} \mathrm{~mol}^{-1}$ and $46.4 \mathrm{~J} \mathrm{~K}^{-1} \mathrm{~mol}^{-1}$, respectively. These values are in good agreement with those available in the literature $[78,86,87]$. The substitution of $\mathrm{La}$ by $\mathrm{Ce}$ in the $\mathrm{LaY}_{2} \mathrm{Ni}_{9}$ parent alloy reduces the value of the enthalpy from -42.6 to $-48.3 \mathrm{~kJ} \mathrm{~mol}^{-1}$, which is explained by the positive effect of cerium on the stability of the electrode.

\section{Conclusion}

The hydrogen absorption and desorption kinetics in $\mathrm{AB}_{3}$ type alloys was studied for $\mathrm{CeY}_{2} \mathrm{Ni}_{9}$. This material will be used as the negative electrode of $\mathrm{Ni}-\mathrm{MH}$ rechargeable battery and also as the hydrogen storage device. The parent alloy of this electrode is $\mathrm{LaY}_{2} \mathrm{Ni}_{9}$ and $\mathrm{La}$ is substituted by Ce to be more attractive for cost-effectiveness. This substitution lowers the electrochemical capacity from 258 to $143 \mathrm{mAh} \mathrm{g}^{-1}$. However, it improves the activation as well as the reversibility of the hydrogen absorption reaction, the exchange current density, the $\mathrm{HRD}$ at 40 and $50{ }^{\circ} \mathrm{C}$ and it maintains the capacity conservation. This substitution reduces also the activation energy, therefore the absorption of hydrogen becomes easier. The value of the enthalpy decreases from -42.6 to $-48.3 \mathrm{~kJ} \mathrm{~mol}^{-1}$ indicating a positive effect of Ce on the stability of the electrode.

The correlation between the evolution of redox, kinetic and thermodynamic parameters is also observed for the $\mathrm{CeY}_{2} \mathrm{Ni}_{9}$ alloy during activation and a long cycling. Indeed, despite the slight decrease of the kinetic parameter values during the long cycling, under the replacement effect of $\mathrm{La}$ by $\mathrm{Ce}$, a reduction in the number of activation cycles and an improvement of cycling stability parameter are observed. 


\section{Acknowledgments}

The authors would like to express their gratitude to Dr. Latroche (LCMTR, CNRS, France) for having offered them the opportunity to prepare the alloys in his laboratory. This work was partly supported by the scientific cooperation under "CMCU-PHC Utique: 10G1208". 


\section{References}

1. Annemieke WC, van den Berg and Carlos Otero Arean (2008) Chem Comm 668-681 DOI: $10.1039 / \mathrm{b} 712576 \mathrm{n}$

2. Feng F, Geng M, Northwood D.O, (2001) Int J Hydrogen Energy 26:725-734

3. Soria ML, Chacon J, Hernandez JC, (2001) J Power Sources 102:97-104

4. Anani A, Visintin A; Petrov K, Srinivasan S, Reilly JJ, Johnson JR, Schwarz RB, Desch PB (1994) J Power Sources 47:261-275.

5. Hong, K (2001) J Power Sources 96:85-89

6. Cuevas F, Joubert JM, Latroche M, Percheron-Guégan A(2001) Appl Phys A 72:225238

7. Petrii OA, Levin EE (2007) Russ. J. General Chem 77:790-796

8. Liu Y, Pan H, Gao M, Wang Q (2011) J Mater Chem 21:4743-4755

9. Fetcenko MA, Ovshinsky SR, Reichman B, Young K, Fiero C, Zallen J, Mays W and Ouchi T (2007) J Power Sources 165:544-551

10. Armand M, Tarascon JM, (2008) Nature 451:652

11. Whittingham MS, (2004) Chem. Rev. 104:4271-4301

12. Etacheri V, Marom R, Elazari R, Salitra G, Aurbach D, (2011) Energy Environ Sci $4: 3243$

13. Young Kh and Nei J (2013) Materials 6: 4574-4608

14. Young K, Ouchi T, Mays W, Reichman B, Fetcenko MA (2009) J Alloys Compd 480:434-439

15. Young K, Ouchi T, Fetcenko MA (2009) J Alloys Compd 480:428-433

16. Xu Y, Chen Y, Wu J, Decheng Li D, Ju H, Zheng J (2010) ) Int J Hydrogen Energy $35: 6366-6380$

17. Xu YH, Chen CP, Wang XL, Wang QD (2002) J Alloys Compd 335:262-265 
18. Tliha M, Mathlouthi H, Lamloumi J, Percheron-Guégan A (2007) Int J Hydrogen Energy 32:611-614

19. Sun J, Fan Y, Liu B, Ji L, Wang Y, Ma M (2015) J Alloy Compd 641:148-154

20. Liu K, Shang J, Ouyang Z, Duan Y, Xing C, Fu Y, Liang F, Lin J, Liu W, Wang L (2015) J Alloy Compd 630:158-162

21. Feng F, Northwood DO (2004) Int J Hydrogen Energy 29:955-960

22. Ben Moussa M, Abdellaoui M, Lamloumi J, Percheron Guégan A (2013) J Alloy Compd 575:414-418

23. Li X, Dong H, Zhang A, Wei Y (2006) J Alloy Compd 426:93-96

24. Taniguchi A, Fujioka N, Ikoma M, Ohta A (2001) J Power Sources 100:117-124

25. Jung DY, Lee BH, Kim SW (2002) J Power Sources 109:1-10

26. Lichtenberg F, Kohler U, Folzer A, Adkins NJE, Zuttel A (1997) J Alloys Compd 253-254: $570-573$

27. Gifford P, Adams J, Corrigan D, Venkatesan S (1999) J Power Sources 80: 157-163

28. Qiu SJ, Chu HL, ZhangY, Sun DL, Song XY, Sun LX, Xu F (2009) J Alloys Compd 471:453-456

29. Chai Y, Li Z, Yin W, Zhang X, Zhao M (2006) J Appl electrochem 36:739-743

30. Qiao Y, hao M, Li M, Zhu X and Cao G (2006) Scripta Materialia 55:279-282

31. Lin J, ChengY, Liang F, Sun L, Yin D, Yaoming Wu Y, Wang L (2014) Int J Hydrog Energy 39: 13231-13239

32. Ben Moussa M, Abdellaoui M, Khaldi C, Mathlouthi H, Lamloumi J, Percheron Guégan A (2005) J Alloys Compd 399:264-269

33. Tliha M, Mathlouthi H, Khaldi C, Lamloumi J, Percheron-Guégan A (2006) J Power Sources 160:1391-1394 
34. Khaldi C, Boussami S, Ben Rejeb B, Mathlouthi H, Lamloumi J (2010) Mater Sci Eng B 175:22-28

35. Khaldi C, Mathlouthi H, Lamloumi J, Percheron-Guegan A (2003) J Alloys Compd $360: 266-271$

36. Mathlouthi H, Khaldi C, Ben Moussa M, Lamloumi J, Percheron-Guegan A (2004) J Alloys Comp 375:297-304

37. Khaldi C, Mathlouthi H, Lamloumi J, Percheron-Guegan A (2008) Phys Chem News 40:139-142

38. Khaldi C, Mathlouthi H, Lamloumi J, Percheron-Guegan A (2006) Phys Chem News $29: 76-80$

39. Liu Y, Cao Y, Huang L, Gao M, Pan H (2011) J Alloys Compd 509:675-686

40. Khaldi C, Mathlouthi H, Lamloumi J, Percheron-Guégan A (2004) Int J Hydrogen Energy 29:307-311

41. Shen CC, Perng TP (2005) J Alloys Comp 392:187-191

42. Kondo M, Asano K, Iijima Y (2005) J Alloys Comp 393:269-273

43. Popović MM, Grgur BN, Vojnović MV, Rakin P, Krstajić NV (2000) J Alloys Compd 298:107-113

44. Tliha M, Khaldi C, Boussami S, Fenineche N, El-Kedim O, Mathlouthi H, Lamloumi J (2014) J Solid State Electrochem 18:577-593

45. Zhang X, Chai Y, Yin W, and Zhao M (2004) J Solid State Chem 177:2373-2377

46. Wei X, Tang R, Liu Y, Zhang P, Yu G, Zhu J (2006) Int J Hydrogen Energy 31:13651371

47. Srivastava S, Upadhyay RK (2007) Int J Hydrogen Energy 32:4195-4201 
48. Wei X, Liu S, Dong H, Zhang P, Liu Y, Zhu J, Yu G (2007) Electrochim Acta $52: 2423-2428$

49. Laurencelle F, Dehouche Z, Goyette J (2006) J Alloys Compd 424:266-271

50. Tan Z, Yang Y, Li Y, Shao H (2008) J Alloys Compd 453:79-86

51. Ye H, Xia B, Wu W, Du K, Zhang H (2002) J Power Sources 111:145-151

52. Chen J, Takeshita HT, Tanaka H, Kuriyama N, Sakai T, Uehara I, Haruta M (2000) J Alloys Compd 302:304-313

53. Zhang Y, Wang H, Zhai T, Yang T, Qi Y, Zhao D (2014) Int J Hydrogen Energy $39: 3790-3798$

54. Knotek V, Vojtečh D (2013) Int J Hydrogen Energy 38:3030-3040

55. Tian X, Yun G, Wang H, Shang T, Yao Z, Wei W, Liang X (2014) Int J Hydrogen Energy 39:8474-8481

56. Jiang W, Lan Z, Xu L, Li G, Guo J (2009) Int J Hydrogen Energy 34:4827-4832

57. Zhao X, Ma L (2009) Int J Hydrogen Energy 34:4788-4796

58. Kohno T, Yoshida H, Kawashima F, Inaba T, Sakai I, Yamamoto M, Kanda M (2000) J Alloys Compd 311:L5-L7

59. Cheng LF, Wang YX, Wang RB, Pu ZH, Zhang XG, He DN (2009) Int J Hydrogen Energy 34:8073-8078

60. Xiangqian S, Yungui C, Mingda T, Chaoling W, Gang D, Zhenzhen K (2009) Int J Hydrogen Energy 34:3395-3403

61. Li Y, Han D, Han S, Zhu X, Hu L, Zhang Z, Liu Y (2009) Int J Hydrogen Energy $34: 1399-1404$

62. Pan H, Jin Q, Gao M, Liu Y, Li R, Lei Y (2004) J Alloys Compd 373:237-245 
63. Zhang XB, Sun DZ, Yin WY, Chai YJ, Zhao MS (2005) Electrochimica Acta 50:1957-1964

64. Zhang F, Luo Y, Deng A, Tang Z, Kang L, Chen J (2006) Electrochimica Acta 52:2432

65. Pan H, Jin Q, Gao M, Liu Y, Li R, Lei Y, Wang Q (2004) J Alloys Compd 376:196204

66. Jiang W, Lan Z, Xu L, Li G, Guo J (2009) Int J Hydrogen Energy 34:4827-4832

67. Tang R, Liu Y, Zhu C, Zhu J, Yu G (2006) Mater Chem Phys 95:130-134

68. Kadir K, Sakai T, Uehara I (2000) J Alloys Compd 302:112-117

69. Denys RV, Riabov AB, Yartys VA, Sato M, Delaplane RG (2008) J Solid State chem $181: 812-821$

70. Ben Belgacem Y, Khaldi C, Boussami S, Lamloumi J, Mathlouthi H (2014) J Solid State Electrochem 18:2019-2026

71. Khaldi C, Mathlouthi H, Lamloumi J, Percheron-Guégan A (2004) J Alloys Comp $384: 249-253$

72. Boussami S, Khaldi C, Lamloumi J, Mathlouthi H, Takenouti H (2012) Electrochim Acta 69:203-208

73. Li CJ, Wang FR, Cheng WH, Li W, Zhao WT (2001) J Alloys Compd 315:218-223

74. Ben Belgacem Y, Khaldi C, Lamloumi J, Takenouti H (2015) J Alloys Compd 631:714

75. Liu Y, Pan H, Yue Y, Wu X, Chen N, Lei Y (2005) J Alloys Compd 395:291-299

76. Zheng G, Popov BN and White RE (1995) J Electrochem Soc 142:2695-2698

77. Raju M, Ananth MV, Vijayaraghavan L (2009) Electrochimica Acta 54:1368-1374 
78. Raju M, Ananth MV, Vijayaraghavan L (2008) J Power Sources 180:830-835

79. Khaldi C, Boussami S, Tliha M, Azizi S, Fenineche N, El-Kedim O, Lamloumi J (2013) J Alloys Comp 574:59-66

80. Liu Y, Pan H, Gao M, Zhu Y, Lei Y, Wang K (2004) Int J Hydrogen Energy 29:297305

81. Ayari M, Paul-Boncour V, Lamloumi J, Mathlouthi H, Percheron-Guégan A (2006) J Alloys Compd 420:251-255

82. Mani N, Ramaprabhu S (2004) J Alloys Compd 363:275-291

83. Hou CP, Zhao MS, Li J, Huang L, Wang YZ, Yue M (2008) Int J Hydrogen Energy $33: 3762-3766$

84. Kleperis J, Wójcik G, Czerwinski A, Skowronski J, Kopczyk M, BeltowskaBrzezinska M (2001) J Solid State Electrochem 5:229-249

85. K. Hong, Method for preparing materials for hydrogen storage and for hydride electrode applications. US patent 5,006,328; 1991.

86. Giza K, Iwasieczko W, Pavlyuk VV, Bala H, Drulis H (2008) J Power Sources $181: 38-40$

87. Giza K, Iwasieczko W, Pavlyuk VV, Bala H, Drulis H (2007) J. Alloys Compd. 429:352-356 